\title{
IL-1 $\beta$ and IFN- $\gamma$ induce the expression of diverse chemokines and IL-15 in human and rat pancreatic islet cells, and in islets from pre-diabetic NOD mice
}

\author{
A. K. Cardozo ${ }^{1,2}$, P. Proost ${ }^{3}$, C. Gysemans ${ }^{4}$, M.-C. Chen ${ }^{2}$, C. Mathieu ${ }^{4}$, D. L. Eizirik ${ }^{1,2}$ \\ ${ }^{1}$ Laboratory of Experimental Medicine, Université Libre de Bruxelles, Brussels, Belgium \\ ${ }^{2}$ Gene Expression Unit, Diabetes Research Centre, Vrije Universiteit Brussel, Brussels, Belgium \\ ${ }^{3}$ Laboratory of Molecular Immunology, Rega Institute for Medical Research, Katholieke Universiteit Leuven, Leuven, Belgium \\ ${ }^{4}$ Laboratory for Experimental Medicine and Endocrinology (LEGENDO), Katholieke Universiteit Leuven, Leuven, Belgium
}

\begin{abstract}
Aims/hypothesis. Cytokines and chemokines are important mediators of immune responses due to their ability to recruit and activate leukocytes. Using microarray analysis we observed that rat beta cells exposed to IL-1 $\beta$ and IFN- $\gamma$ have increased mRNA levels of chemokines and IL-15. The aim of this study was to characterize the expression of IP-10, MIP-3 $\alpha$, fractalkine and IL-15 in rat beta cells, human pancreatic islets, and in islets isolated from NOD mice, both during the pre-diabetic period and following islet transplantation.

Methods. FACS-purified rat beta cells and human islets were cultured with IL- $1 \beta$, IFN- $\gamma$ and/or TNF- $\alpha$. Islets were isolated from NOD or BALB/c mice at different ages. For syngeneic islet transplantation, 2- or 3-week-old NOD islets were grafted under the kidney capsule of spontaneously diabetic NOD recipients. Chemokine and IL-15 mRNA expression and protein release were evaluated, respectively, by RT-PCR and ELISA.
\end{abstract}

Results. Human islets and rat beta cells express IP-10, MIP-3 $\alpha$, fractalkine and IL-15 mRNAs upon exposure to cytokines. The expression of IL-15, IP-10 and fractalkine is regulated by IFN- $\gamma$, while the expression of MIP-3 $\alpha$ is IL-1 $\beta$-dependent. Moreover, cytokines induced IL-15, IP-10, Mig, I-TAC and MIP-3 $\alpha$ protein accumulation in culture medium from human islets. In vivo, there was an age-related increase in IL-15, IP-10 and MIP-3 $\alpha$ expression in islets isolated from NOD mice. Following syngeneic islet transplantation, increased expression of IL-1 $\beta$, IFN- $\gamma$, fractalkine, IP-10, MCP-1 and MIP-3 $\alpha$ mRNAs were observed in the grafts.

Conclusion/interpretation. Cytokine-exposed islets or beta cells express chemokines and IL-15. This could contribute to the recruitment and activation of mononuclear cells and development of insulitis in early Type 1 diabetes and during graft destruction. [Diabetologia (2003) 46:255-266]

Keywords Type 1 diabetes mellitus, chemokines, IL-15, NOD mice, beta cells, interferon- $\gamma$, interleukin- $1 \beta$, pancreatic islets, islet transplantation, insulitis.
Received: 16 May 2002 / Revised: 30 July 2002

Published online: 12 February 2003

C) Springer-Verlag 2003

Corresponding author: D. L. Eizirik, Laboratory of Experimental Medicine, Université Libre de Bruxelles, Route de Lennik, 808, CP 618, 1070 Brussels, Belgium

E-mail: deizirik@ulb.ac.be

Abbreviations: BB, BioBreeding; IP-10, interferon inducible protein-10; I-TAC, IFN-inducible T-cell $\alpha$ chemoattractant; MCP-1, monocyte chemoattractant protein-1; Mig, monokine induced by IFN- $\gamma$; MIP-3 $\alpha$, macrophage inflammatory protein- $3 \alpha$; NK, natural killer; NOD, non-obese diabetic; Th1, T-helper 1.
Insulin deficiency in Type 1 diabetes mellitus results from an autoimmune destruction of pancreatic beta cells [1]. Rodent models of Type 1 diabetes, such as BioBreeding (BB) rats and non-obese diabetic (NOD) mice, are important tools for the study of Type 1 diabetes, since they share many features of the human disease [2, 3]. In NOD mice, a non-destructive insulitis develops after weaning. Antigen presenting cells such as macrophages and dendritic cells appear early, followed by CD4+ (T helper) and CD8+ (cytotoxic) T-cell and beta-cells [3]. This early insulitis is located around the islets and it becomes destructive when the mononuclear cells progressively invade the islets, 
leading to destruction of beta cells and hyperglycaemia around 22 weeks of age $[2,3,4]$. Although insulitis is evenly distributed between sexes, prevalence of diabetes is higher in females than in males [2, 4, 5]. The putative mediators of beta-cell death in NOD mice include cytokines, such as interleukin-1 $\beta$ (IL-1 $\beta$ ) and interferon- $\gamma$ (IFN- $\gamma$ ), perforin, free-radicals and FAS-ligand $[3,6]$. The mechanisms involved in the attraction of mononuclear cells to the islets, and subsequent beta-cell destruction, are yet to be clarified. We have previously reported that rat and human islet cells, and islets isolated from pre-diabetic NOD mice, express the monocyte chemoattractant protein-1 (MCP-1) [7, 8]. In subsequent experiments, based on microarray analysis, we observed that rat beta cells exposed to the cytokines IL- $1 \beta$ and IFN- $\gamma$ have increased expression of mRNAs for the chemokines interferon inducible protein-10 (IP-10), macrophage inflammatory protein-3 $\alpha$ (MIP-3 $\alpha)$, fractalkine and the cytokine interleukin-15 (IL-15) [9]. Induction of several of these chemokines is regulated via activation of NF-KB [10].

Chemokines are small heparin-binding proteins that regulate innate and adaptive immune responses by contributing to the activation of leucocytes [11]. They are produced by a variety of stimulated cells during inflammatory processes, and have been implicated as important mediators of acute and chronic inflammatory disorders in man [12]. IP-10 is part of the CXC family of chemokines, attracting activated T-helper 1 (Th1) and natural killer (NK) cells expressing the CXCR3 receptor $[13,14]$. IP-10 plays a role in lymphocyte recruitment in autoimmune thyroid disorders [15] and demyelinating neuropathies [16, 17]. Moreover, high serum levels of IP-10 are seen in Type 1 diabetic patients [18]. MIP-3 $\alpha$ is a CC chemokine which attracts memory T-lymphocytes and dendritic cells expressing the CCR6 receptor $[19,20,21]$. The expression of MIP-3 $\alpha$ is up-regulated in psoriatic skin [22], atopic dermatitis [23] and rheumatoid arthritis [24] and MIP$3 \alpha$ is involved in the amplification of local inflammatory responses in the liver [25]. Fractalkine is the single member of the CX3C family of chemokines. It is a unique chemokine since it is located on a membrane bound mucin stalk and is in transmembrane and soluble shed forms [26]. Fractalkine has adhesive properties, promoting leukocyte migration and enhancing the cytotoxicity of NK cells [27] and cytotoxic T-lymphocytes [28]. Fractalkine has an important role in cardiac allograft rejection [29, 30], and it is expressed in mononuclear cells during renal inflammation [31]. The cytokine IL-15 is a potent growth factor and activator of T-cells and NK-cells. It also acts as a T-cell chemoattractant and inducer of IFN- $\gamma$ production by NK-cells [32]. Available data suggest that IL-15 contributes to the pathogenesis of inflammatory disorders such as rheumatoid arthritis, sarcoidosis, chronic hepatitis C and ulcerative colitis [32].
In the current study we characterized the expression of IP-10, MIP-3 $\alpha$, fractalkine and IL-15 in rat beta cells and human pancreatic islets exposed to cytokines. Moreover, expression of these chemokines was evaluated in islets isolated from NOD mice, both during the pre-diabetic period and following syngeneic islet transplantation.

\section{Materials and Methods}

Islet cell preparation, culture and exposure to cytokines. Pancreatic islets were isolated from adult Wistar rats and C57BL6 mice by collagenase digestion. Rat islet beta cells were purified by autofluorescence-activated cell sorting (FACS) [33]. Pancreatic islets were dispersed in calcium-free HEPESbuffered Earle's medium (EH) containing $1 \mathrm{mmol} / \mathrm{l}$ EGTA, $25 \mu \mathrm{g} / \mathrm{ml}$ trypsin and $2 \mu \mathrm{g} / \mathrm{ml}$ DNase. Isolated cells were diluted in calcium-free EH buffer and filtered through a $63-\mu \mathrm{m}$ nylon screen to remove cell clumps and undigested material. An isotonic Percoll solution density $1.040 \mathrm{~g} / \mathrm{ml}$ was layered underneath the filtrate in order to remove debris and dead cells during a subsequent centrifugation at $300 \times \mathrm{g}$ for $6 \mathrm{~min}$. The Percoll pellet was collected, suspended in $50 \mathrm{ml}$ of Ham's-F10 medium containing $2 \mathrm{mmol} / \mathrm{l}$ glutamine and $0.2 \% \mathrm{BSA}$, and incubated for $20 \mathrm{~min}$ at $37^{\circ} \mathrm{C}$ under $7.5 \% \mathrm{CO}_{2}$. After this incubation period the cells were pelleted and suspended in $\mathrm{EH}$ containing $2.8 \mathrm{mmol} / \mathrm{l}$ glucose and $0.5 \% \mathrm{BSA}$ and submitted to FACS sorting (FACStar, Becton-Dickinson, Sunnyvale, Calif., USA). An argon laser illuminated the cells at $488 \mathrm{~nm}$, so that the emission at $510-550 \mathrm{~nm}$ could be taken as a parameter for their flavin adenine dinucleotide (FAD) content. At $2.8 \mathrm{mmol} / \mathrm{l}$ glucose and at $17^{\circ} \mathrm{C}$, beta cells had a three-fold higher FAD fluorescence than single non beta cells, while the light scatter activity is $50 \%$ larger. Selection of an appropriate window allows isolation of single beta cells that are 90 to $95 \%$ pure [33]. Beta-cell aggregates and mouse islets were cultured in suspension at $37^{\circ} \mathrm{C}$ in Ham's F10 medium (Invitrogen, Paisley, Scotland) [34]. After overnight culture, they were exposed for $6 \mathrm{~h}$ or $24 \mathrm{~h}$ to IL-1 $\beta$ and/or IFN- $\gamma$, and then harvested for mRNA extraction (see below). Recombinant human IL-1 $\beta$ (tested at $50 \mathrm{U} / \mathrm{ml} ; 38 \mathrm{U} / \mathrm{ng}$ ) was the kind gift of Dr. C.W. Reinolds, National Cancer Institute, Bethesda, Md., USA and mouse IFN- $\gamma$ (tested at $1000 \mathrm{U} / \mathrm{ml} ; 10 \mathrm{U} / \mathrm{ng}$ ) was purchased from Invitrogen, Paisley, Scotland. Human islet cells were isolated from pancreases obtained from five adult heart-beating organ donors [8]. The mean donor age $( \pm$ SEM) was $21 \pm 6$ years and the islet preparations contained $70 \pm 2 \%$ beta cells and $15 \%$ alpha cells, as assessed by immunocytochemistry and electron microscopy $[33,35]$. For the RT-PCR experiments, human islets cells $\left(10^{5}\right)$ were cultured in Ham's F10 medium [36], and exposed for $6 \mathrm{~h}$ or $24 \mathrm{~h}$ to recombinant human IL-1 $\beta(50 \mathrm{U} / \mathrm{ml})$, recombinant human IFN- $\gamma$ (1000 U/ml, Genzyme, Cambridge, USA) and the iNOS blocker $\mathrm{N}^{\mathrm{G}}$-methyl-L-arginine (L-MA, $1.0 \mathrm{mmol} / \mathrm{l}$; Sigma, Bornem, Belgium), alone or in combinations. For measurements of cytokine or chemokine release by ELISA, human islets cells $\left(10^{5}\right)$ were cultured for $72 \mathrm{~h}$ with or without recombinant human IL-1 $\beta(50 \mathrm{U} / \mathrm{ml})$, recombinant human IFN- $\gamma$ $(1000 \mathrm{U} / \mathrm{ml})$ and recombinant murine TNF- $\alpha$ (1000 U/ml, Innogenetics, Zwijnaarde, Belgium). The choice of cytokine and L-MA concentrations are based on our previous data $[6,8$, 9]. All experimental procedures described in this and the sessions mentioned below were approved and carried out in accordance with the Ethics Committees of the Vrije Universiteit Brussel, Université Libre de Bruxelles, Katholieke Universiteit 
Leuven and the European Hospitals affiliated with the Eurotransplant Foundation (Leiden, The Netherlands) and $\beta$-Cell Transplant (Brussels, Belgium).

Isolation and transplantation of islets from NOD mice. A colony of NOD mice has been inbred since 1990 at the Animal Breeding Centre of the Catholic University of Leuven (Belgium) and these mice were maintained under semi-barrier conditions [37]. At the time of the present experiments, $73 \%$ of the female mice have overt diabetes at 28 weeks of age, while the diabetes incidence was lower in male mice (12\%). Insulitis occurs at a similar age and approximately to the same extent in male and female NOD mice from our colony [8]. BALB/c mice were purchased from Harlan CBP (Zeist, The Netherlands) and were used as non-diabetes-prone control mice.

For mRNA analysis in islets from native pancreases, islets were prepared from 2- to 12-week-old male and female NOD mice as well as from 4-week-old male and female BALB/c mice [38]. Islets were isolated from the pancreas by collagenase digestion in cold Hank's salt solution followed by hand picking under a stereomicroscope. Islets were frozen in liquid nitrogen and stored at $-80^{\circ} \mathrm{C}$ until use.

For syngeneic islet transplantation into diabetic NOD mice (an experimental model for the recurrence of autoimmune beta-cell destruction, [38, 39]), 2- or 3-week-old NOD islets $(n=500)$ were grafted after avertin anesthaesia under the left kidney capsule of both male and female spontaneously diabetic NOD recipients, ranging in age from 4 to 6 months. Note that 2- or 3-week-old NOD mice from our colony were normoglycaemic and did not have detectable insulitis [8]. NOD islets transplanted in spontaneously diabetic NOD mice had a mean survival time of $9.2 \pm 2.2$ days (range between $8-15$ days; $n=15$ ). For syngeneic islet transplantation in a non-diabetic mouse strain, 2- or 3-week-old BALB/c islets $(n=500)$ were grafted after avertin anaesthesia under the left kidney capsule of both male and female $\mathrm{BALB} / \mathrm{c}$ recipients, ranging in age from 4 to 6 months. Animals were killed under anaesthesia $8 \mathrm{~h}$ or 6 days $(n=4)$ after transplantation for mRNA analysis of the islet grafts. Kidney tissue was also retrieved, and utilized here as "background mRNA expression". Both islet grafts and kidney tissue were frozen in liquid nitrogen and stored at $-80^{\circ} \mathrm{C}$ until use.

Analysis of mRNA expression. The selection of RT-PCR, instead of Northern-blot analysis, was motivated by the limited availability of primary beta cells. For the experiments with rat beta cells and human islets mRNA isolation and RT-PCR were carried out as previously described $[7,40]$. The number of cycles was selected to allow linear amplification of the cDNAs under study. For semi-quantitative PCR, the housekeeping gene glyceraldehyde 3-phosphate dehydrogenase (GAPDH) was utilized as controls. We have previously shown $[10,40]$, that IL-1 $\beta$ and IFN- $\gamma$ do not affect GAPDH mRNA expression in primary beta cells. The primer sequences and their respective PCR fragment lengths for the human genes were as follows: hIL-15: F $5^{\prime}-\mathrm{GA}$ TGGATGGCTGCTGGAAAC-3', R 5'-GCATCTCCGGACTCAAGTGA-3' (390 bp); hIP-10: F 5'-CCACGTGTTGAGATCATTGC-3', R 5'-ACATAGCACCTCAGTAGAGC-3' (382 bp); hMIP-3 $\alpha$ : F 5'-GTGCTGTACCAAGAGTTTGC-3', R 5'-GACAAGTCCAGTGAGGCACA-3' (420 bp); hFractalkine: F 5'-ACGCACAGGCGAAAGCAGTA-3'， R 5'-TTCAGACGGAGCATTCTCCT-3' (340 bp); GAPDH: F 5'-CATGTTCGTCATGGGTGTGA-3'， R 5'-AGTGAGCTTCCCGTTCAGCT-3' (300 bp). The rat primers for GAPDH, IL-15, IP-10, MIP-3 $\alpha$ and fractalkine were as described [9]. The ethidium bromidestained agarose gels were photographed under UV-transillumination using a Kodak Digital Science DC 120 camera
(Kodak, Rochester, N.Y., USA). Abundance of the GAPDH products were assessed by Biomax 1D image analysis software (Kodak) and expressed in pixel intensities (OD). The data are shown as a representative figure for three to five similar experiments.

For the in vivo (NOD and BALB/c mice) and in vitro (mouse islets) experiments with mouse material, real-time quantitative RT-PCR analysis of pancreatic islets and syngeneic islet grafts was carried out. Total RNA was isolated from fresh pancreatic islets $(n=200)$ using the High Pure RNA isolation kit (Roche Diagnostics, Indianapolis, Ind., USA) resulting in DNA-free RNA, while for total RNA extraction from the islet grafts and the control kidney tissue TRIzol Liquid Suspension reagent (Life Technologies, Gaithersburg, Md., USA) was used. After reverse transcription with Superscript II reverse transcriptase (Life Technologies), real-time quantitative PCR was done in the ABI Prism 7700 Sequence Detector (Perkin Elmer/Applied Biosystems, Foster City, Calif., USA) for IL-1 $\beta$, IFN- $\gamma$, IL-15, fractalkine, IP-10 and MIP-3 $\alpha$ [41]. PCR amplification reactions $(25 \mu \mathrm{l})$ contained $0.5 \mu \mathrm{l}$ cDNA sample, $2.5 \mu \mathrm{l} 10 \times$ TaqMan Buffer A, $200 \mu \mathrm{mol} / \mathrm{l} \mathrm{dNTPs}, 5 \mathrm{mmol} / \mathrm{l}$ $\mathrm{MgCl}_{2}, 0.625 \mathrm{U}$ AmpliTaq Gold, 200 to $300 \mathrm{nmol} / \mathrm{l}$ of primerforward (F) and 200 to $900 \mathrm{nmol} / \mathrm{l}$ of primer-reverse (R) (Table 1). The reaction also contained the corresponding detection probe (50 to $100 \mathrm{nmol} / \mathrm{l}$ ) (Table 1). Each amplification was carried out in triplicate wells, using the following conditions: $2 \mathrm{~min}$ at $50^{\circ} \mathrm{C}$ and $10 \mathrm{~min}$ at $94^{\circ} \mathrm{C}$, followed by a total of 45 two-temperature cycles $\left(15 \mathrm{~s}\right.$ at $94^{\circ} \mathrm{C}$ and $1 \mathrm{~min}$ at $\left.60^{\circ} \mathrm{C}\right)$. A normalisation to $\beta$-actin (in vivo experiments) or GAPDH (in vitro experiments) as "housekeeping" genes was done for each sample. The method used for quantification by real time PCR is the standard-curve method, as described in previous publications by our group $[41,42]$.

ELISA. Culture media from human islets exposed for $72 \mathrm{~h}$ to cytokines or control (no cytokines added) conditions were collected and stored at $-20^{\circ} \mathrm{C}$ until analysis by ELISA. Samples were assayed for human IL-15 and MIP- $3 \alpha$ using commercially available ELISAs (R \& D systems, Abingdon, UK, sensitivity $1.9 \mathrm{pg} / \mathrm{ml}$ ). Human IP-10, Mig and I-TAC were detected in classical sandwich ELISAs. For IP-10, anti-human IP-10 monoclonal antibody (Ab) (R \& D systems, Abingdon, UK) was used for coating, the biotinylated anti-human IP-10 polyclonal $\mathrm{Ab}$ ( $\mathrm{R} \& \mathrm{D}$ systems, Abingdon, UK) was used as capturing antibody, the recombinant human IP-10 (Preprotech, London, UK) was used as standard and peroxidase labelled streptavidine (Jackson ImmunoResearch, West Grove, Pa., USA) for detection. For Mig and I-TAC, polyclonal rabbit anti human Ab (PeproTech, London, UK) were used for coating, monoclonal mouse anti $\mathrm{Ab}$ ( $\mathrm{R} \& \mathrm{D}$ systems, Abingdon, UK) were used as capturing $\mathrm{Ab}$ and peroxidase-conjugated affinity purified goat anti mouse $\mathrm{Ab}$ (Jackson ImmunoResearch, West Grove, Pa., USA) were used for detection. The sensitivities of the IP-10, Mig and I-TAC ELISAs were, respectively, $1.9 \mathrm{ng} / \mathrm{ml}, 8 \mathrm{ng} / \mathrm{ml}$ and $0.4 \mathrm{ng} / \mathrm{ml}$ on $1 / 10$ prediluted samples. All the ELISAs were specific in that they did not show cross-reactivity with a broad panel of chemokines, including MCP-1, MCP-2, MCP-3, eotaxin, RANTES, MIP- $1 \alpha$, MIP- $1 \beta$, MIP-3 $\alpha$, PARC, TARC, GCP-2, ENA-78, GRO- $\alpha$, GRO- $\beta$, GRO- $\gamma$, IL-8, SDF-1, IP-10, Mig, I-TAC, PF-4, CTAP-III and NAP-2 (data not shown).

Statistical analysis. Data are shown as means \pm SEM, and comparisons between groups were carried out by ANOVA followed by Student's $t$ test with the Bonferroni correction. A $p$ value of less than or equal to 0.05 was considered as statistically significant. 
Table 1. Primer and probe sequences used in real time PCR

\begin{tabular}{|c|c|c|c|}
\hline & & Sequence $5^{\prime}-3^{\prime}$ & $\begin{array}{l}\text { Amplicon length } \\
\text { (bp) }\end{array}$ \\
\hline$I L-1 \beta$ & $\begin{array}{l}\mathrm{F} \\
\mathrm{R} \\
\mathrm{TP}\end{array}$ & $\begin{array}{l}\text { CAACCAACAAGTGATATTCTCCATG } \\
\text { GATCCACACTCTCCAGCTGCA } \\
\text { CTGTGTAATGAAAGACGGCACACCCACC }\end{array}$ & 152 \\
\hline$I L-15$ & $\begin{array}{l}\mathrm{F} \\
\mathrm{R} \\
\mathrm{TP}^{a}\end{array}$ & $\begin{array}{l}\text { CATCCATCTCGTGCTACTTGTGTT } \\
\text { CATCTATCCAGTTGGCCTCTGT } \\
\text { AGGGAGACCTACACTGACACAGCCCAAAA }\end{array}$ & 126 \\
\hline$I F N-\gamma$ & $\begin{array}{l}\mathrm{F} \\
\mathrm{R} \\
\mathrm{TP} a\end{array}$ & $\begin{array}{l}\text { TCAAGTGGCATAGATGTGGAAGAA } \\
\text { TGGCTCTGCAGGATTTTCATG } \\
\text { TCACCATCCTTTTGCCAGTTCCTCCAG }\end{array}$ & 92 \\
\hline Fractalkine & $\begin{array}{l}\mathrm{F} \\
\mathrm{R} \\
\mathrm{TP}\end{array}$ & $\begin{array}{l}\text { GGGTGGCCATGTTTGCTTAC } \\
\text { CAGGCAAGCAGCTCACACTG } \\
\text { TCCCCCGTAGCTGTGGCAGTAACTCAT }\end{array}$ & 140 \\
\hline$M I P-3 \alpha$ & $\begin{array}{l}\mathrm{F} \\
\mathrm{R} \\
\mathrm{TP}\end{array}$ & $\begin{array}{l}\text { CCAGGCAGAAGCAAGCAACT } \\
\text { TCGGCCATCTGTCTTGTGAA } \\
\text { TGTTGCCTCTCGTACATACAGACGCCA }\end{array}$ & 96 \\
\hline$I P-10$ & $\begin{array}{l}\mathrm{F} \\
\mathrm{R} \\
\mathrm{TP}\end{array}$ & $\begin{array}{l}\text { GCCGTCATTTTCTGCCTCAT } \\
\text { GCTTCCCTATGGCCCTCATT } \\
\text { TCTCGCAAGGACGGTCCGCTG }\end{array}$ & 127 \\
\hline$\beta$-actin & $\begin{array}{l}\mathrm{F} \\
\mathrm{R} \\
\mathrm{TP}\end{array}$ & $\begin{array}{l}\text { AGAGGGAAATCGTGCGTGAC } \\
\text { CAATAGTGATGACCTGGCCGT } \\
\text { CACTGCCGCATCCTCTTCCTCCC }\end{array}$ & 138 \\
\hline
\end{tabular}

a antisense probe

of fractalkine expression by IFN- $\gamma$ or IFN- $\gamma+$ IL- $1 \beta$ (Figs. 1, 2).

IL- $1 \beta+$ IFN- $\gamma$ induces the expression of the inducible form of nitric oxide synthase (iNOS) and nitric oxide (NO) production by both human islets and rat beta cells ([8,43], (current data, not shown). NO modifies the expression of several genes and proteins in beta cells $[10,44,45]$. The addition of the iNOS inhibitor L-MA prevented cytokine-induced NO production by the human islets, but did not affect the induction of mRNAs encoding IL-15 and the chemokines analyzed (Fig. 2), indicating that induction of IL-15, IP-10, MIP-3 $\alpha$ and fractalkine by cytokines is NO independent.

To confirm that IL-15 and chemokine expression occurs in the beta cells, time course experiments were carried out to analyse cytokine-induced expression of IL-15, IP-10, MIP-3 $\alpha$ and fractalkine mRNAs in the clonal rat insulinoma cell line (RINm5F cells). The results obtained at 6,12 and $24 \mathrm{~h}$ were similar to the findings in rat beta cells (Fig. 1) and, as observed in human islets (Fig. 2), the iNOS inhibitor L-MA failed to prevent cytokine-induced chemokine mRNA expression by RINm5F cells (data not shown).

In additional experiments we evaluated whether 6-h exposure of mouse islets (C57BL6 mice) to IL-1 $\beta$ + IFN- $\gamma$ leads to IL-15, IP-10 and MCP-1 mRNA expression. Basal expression (i.e. in the absence of cytokines) for IL-15 and IP-10 were bellow detection limit, while for MCP-1 it was $0.2 \pm 0.1$ A.U. (arbitrary units; MCP-1 divided by GAPDH). Upon exposure to 
IL-15

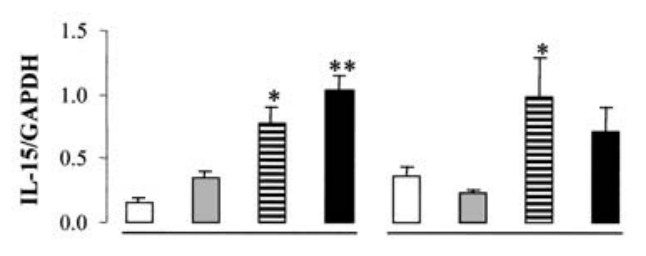

IP-10

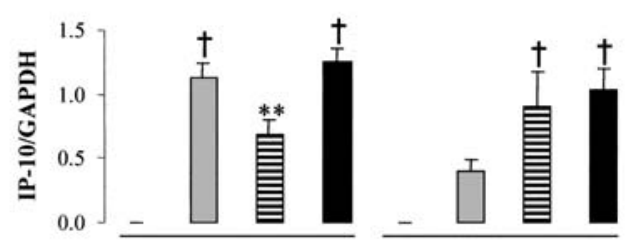

MIP-3 $\alpha$
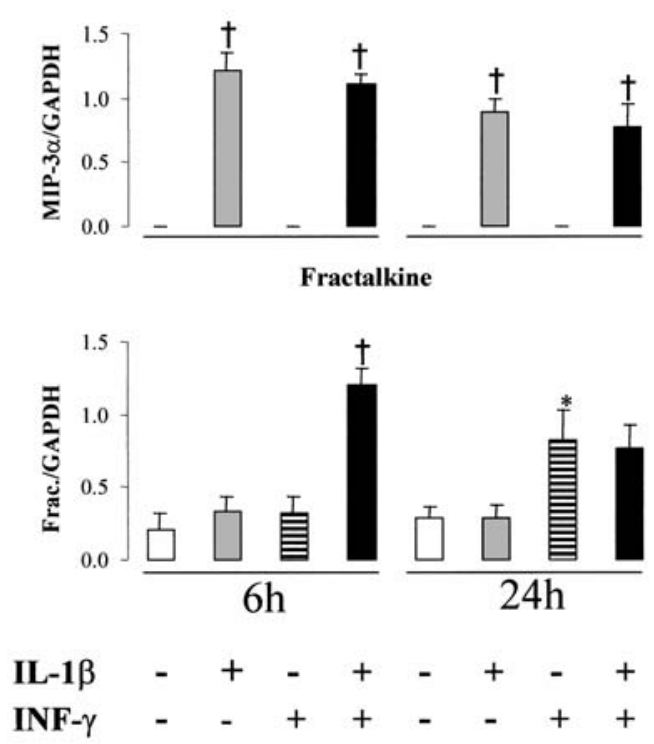

Fig. 1. Cytokines induce an early expression of mRNA for IL-15 and the chemokines IP-10, MIP-3 $\alpha$ and fractalkine in rat purified beta cells. Rat beta cells $\left(5 \times 10^{4}\right.$ cells/condition) were cultured for 6 or $24 \mathrm{~h}$ in control condition (no cytokines added, white bars), IL-1 $\beta$ (50 U/ml, grey bars), IFN $\gamma(1000 \mathrm{U} / \mathrm{ml}$, stripped bars) or $\mathrm{IL}-1 \beta+\mathrm{IFN} \gamma$ (black bars). After these time points the cells were harvested, mRNA extracted and RT-PCR was carried out with the equivalent of $1.5 \times 10^{3}$ cells. PCR band intensities were expressed as OD corrected for GAPDH expression. Data are means \pm SEM of five experiments. ${ }^{*} p \leq 0.05,{ }^{* *} p \leq 0.01,{ }^{\dagger} p \leq 0.001$ vs. corresponding control groups. ANOVA followed by paired $t$-test with Bonferroni correction

cytokines the values were (cytokine/GAPDH) MCP-1 $1.3 \pm 0.2$ A.U. $(n=3)$, IP-10 $0.9 \pm 0.2$ A.U. $(n=3)$, IL-15 $1.1 \pm 0.1$ A.U. $(n=2)$. Thus, and as observed for rat and human islet cells (see above), IL- $1 \beta+$ IFN- $\gamma$ also induces chemokine and IL-15 mRNA expression by isolated mouse islets.

Human islets secrete chemokines and IL-15 after cytokine exposure. To evaluate whether cytokine-induced

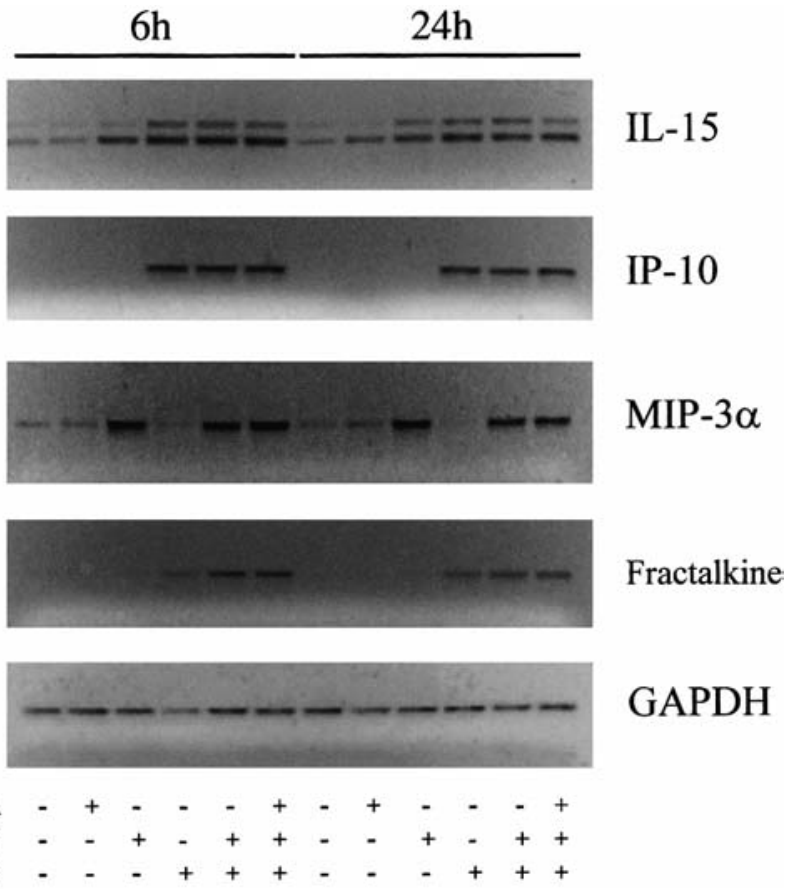

Fig. 2. Effects of cytokines and/or the iNOS inhibitor L-MA on IL-15, IP-10, MIP-3 $\alpha$ and fractalkine mRNA expression by human islet cells. Human islet cells $\left(10^{5}\right.$ cells/well $)$ were cultured for 6 or $24 \mathrm{~h}$ with or without IL-1 $\beta(50 \mathrm{U} / \mathrm{ml}), \mathrm{IFN}-\gamma$ $(1000 \mathrm{U} / \mathrm{ml})$, and the iNOS inhibitor L-MA (1 mmol/l), alone or in combinations. After these time points the cells were harvested, mRNA extracted and RT-PCR was carried out using specific primers with the equivalent of $1.5 \times 10^{3}$ cells. The pictures shown are representative of three to four similar experiments

expression of IL-15, IP-10 and MIP-3 $\alpha$ is associated with protein synthesis and release, human islets were cultured with different cytokines for $72 \mathrm{~h}$ and medium protein accumulation was measured by ELISA (Fig. 3). Human islets released IL-15 under control conditions (no cytokine added). In agreement with the mRNA data, incubation with IFN- $\gamma$ alone lead to an increase in IL-15 accumulation in the medium. Combinations of 2-3 cytokines further increased IL-15 release by the islets (Fig. 3).

IP-10 protein was not detected in the medium of islets exposed to control conditions, but exposure to IFN- $\gamma$ induced a large production of IP-10. IL-1 $\beta$ or TNF- $\alpha$ alone did not induce IP-10 release, but these cytokines potentiated the effects of IFN- $\gamma$, nearly doubling the amount of IP-10 released in the medium. Combinations of the three cytokines resulted in a maximal production of IP-10 (Fig. 3). Two other ligands for the IP-10 receptor CXCR3, namely IFN-Inducible T-cell $\alpha$ Chemoattractant (I-TAC) and Monokine Induced by IFN- $\gamma$ (Mig) [46] were also assessed. Mig and I-TAC protein were below the detection limit in the medium of control islets or islets treated with IL- $1 \beta$ and/or TNF- $\alpha$, but islets exposed to IFN- $\gamma$ released $13.5 \pm 1.2 \mathrm{ng} / \mathrm{ml}$ of Mig and $1.2 \pm 0.4 \mathrm{ng} / \mathrm{ml}$ of I-TAC $(p<0.01$ vs controls, 

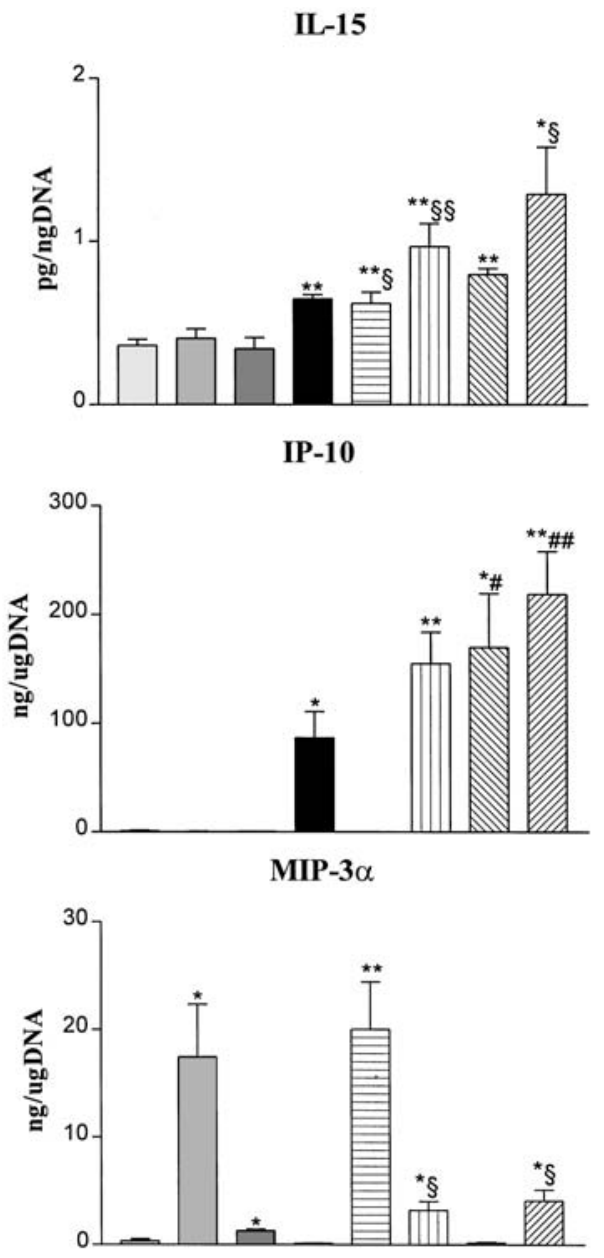

$\begin{array}{lllllllll}\text { IL-1 } \beta & - & + & - & - & + & + & - & + \\ \text { TNF- } \alpha & - & - & + & - & + & - & + & + \\ \text { INF- } \gamma & - & - & - & + & - & + & + & +\end{array}$

Fig. 3. Cytokine-induced IL-15, IP-10 and MIP-3 $\alpha$ protein release by human islet cells. Human islet cells were cultured for $72 \mathrm{~h}$ with or without IL-1 $\beta$ (50 U/ml), IFN- $\gamma(1000 \mathrm{U} / \mathrm{ml})$ and TNF- $\alpha(1000 \mathrm{U} / \mathrm{ml})$, alone or in combinations. The medium was then collected for protein measurements by ELISA. Samples were measured in duplicate and the data shown are means \pm SEM of four independent experiments. ${ }^{*} p \leq 0.05$, ${ }^{* *} p \leq 0.01$ vs. control ; $\S p \leq 0.05$, $\$ p \leq 0.02$ vs. IL- $1 \beta$; ${ }^{\#} p \leq 0.05,{ }^{\#} p \leq 0.01$ vs. IFN- $\gamma$. ANOVA followed by paired $t$-test with Bonferroni correction

means \pm SEM, $n=5)$. IL- $1 \beta$ and/or TNF- $\alpha$ did not potentiate the effects of IFN- $\gamma$ on I-TAC production, but the combination of IL- $1 \beta+$ TNF- $\alpha+$ IFN- $\gamma$ lead to a higher release of $\operatorname{Mig}(23.4 \pm 4.1 \mathrm{ng} / \mathrm{ml})$ as compared to IFN- $\gamma$ alone $(p<0.05, n=5)$. Exposure of human islets to IL-1 $\beta$ induced a 20 -fold increase in MIP-3 $\alpha$ release to the medium and this effect was not modified by TNF- $\alpha$ (Fig. 3). IFN- $\gamma$ exerted a strong inhibitory effect on the production of MIP-3 $\alpha$, reducing its induction by IL- $1 \beta$ by nearly five-fold (Fig. 3).

Expression of cytokine and chemokine mRNAs in isolated pancreatic islets from pre-diabetic NOD mice.
mRNA expression was analysed by real time RT-PCR in islets isolated from pre-diabetic NOD mice between 2 to 12 weeks of age. None of the NOD mice used in this study had glucosuria, and random blood glucose concentrations at the end of the study did not exceed $125 \mathrm{mg} / \mathrm{dl}$. As an external control, islets from 4-weekold non-diabetes-prone $\mathrm{BALB} / \mathrm{c}$ mice were also analysed.

There was a progressive increase in both IL- $1 \beta$ and IFN- $\gamma$ expression in male and female NOD mice, paralleling the early stages of insulitis [8]. Increased IL- $1 \beta$ was already detectable at 6 weeks of age, preceeding the rise in IFN- $\gamma$ (indicating influx of T-lymphocytes) at 8 weeks of age (Fig. 4). IL-15 mRNA expression in islets has a distinct pattern in female and male mice, although insulitis and evolution of cytokine expression are comparable. Whereas islets from female NOD mice already have clearly raised IL-15 expression at 6 weeks, males only have a rise in IL-15 from 10 weeks on (Fig. 4). There was no change in fractalkine expression in NOD islets. Moreover, we observed a lower fractalkine expression in NOD islets than in BALB/c islets. Extremely high IP-10 expression, compared to BALB/c and 2-week-old NOD mouse islets, were present from 4 weeks on in males (10-fold compared to 2-week-old NOD mice) and from 6 weeks on in females (35-fold compared to 2-week-old NOD mice). IP-10 mRNA contents peaked at 10 weeks and were already reduced by 12 weeks (Fig. 4). A clearly different pattern was seen for MIP-3 $\alpha$, where expression was only found from 10 weeks onwards (Fig. 4), when most mice already have florid insulitis [8].

Expression of cytokine and chemokine mRNAs in islet isografts into diabetic NOD mice. Syngeneic islets of young (2-3 weeks old) insulitis-free non-diabetic NOD mice were grafted under the kidney capsule of spontaneously diabetic NOD mice (4-6 months old). To verify cytokine and chemokine production in syngeneic islets of a non-diabetes-prone mouse strain, $\mathrm{BALB} / \mathrm{c}$ islets were grafted under the kidney capsule of adult BALB/c mice. Animals were killed $8 \mathrm{~h}$ or 6 days after transplantation and mRNA analysis of the islet grafts and kidney tissue (control) was carried out.

An early $(8 \mathrm{~h})$ increase in IL- $1 \beta$ was observed in both NOD and BALB/c islets, probably due to nonspecific tissue damage secondary to islet grafting (Fig. 5A). IFN- $\gamma$ expression was comparable to those in background kidney tissue after $8 \mathrm{~h}$, and did not increase in NOD grafts until $48 \mathrm{~h}$ after transplantation (data not shown), suggesting absence of T-lymphocytes in the early hours following transplantation. An increase in IP-10 expression was observed in both NOD and BALB/c mice, but IP-10 expression was nearly 30-fold higher in NOD mice then in BALB/c mice (Fig. 5A). In addition, NOD mice IP-10 mRNA was increased eight-fold when compared to kidney 

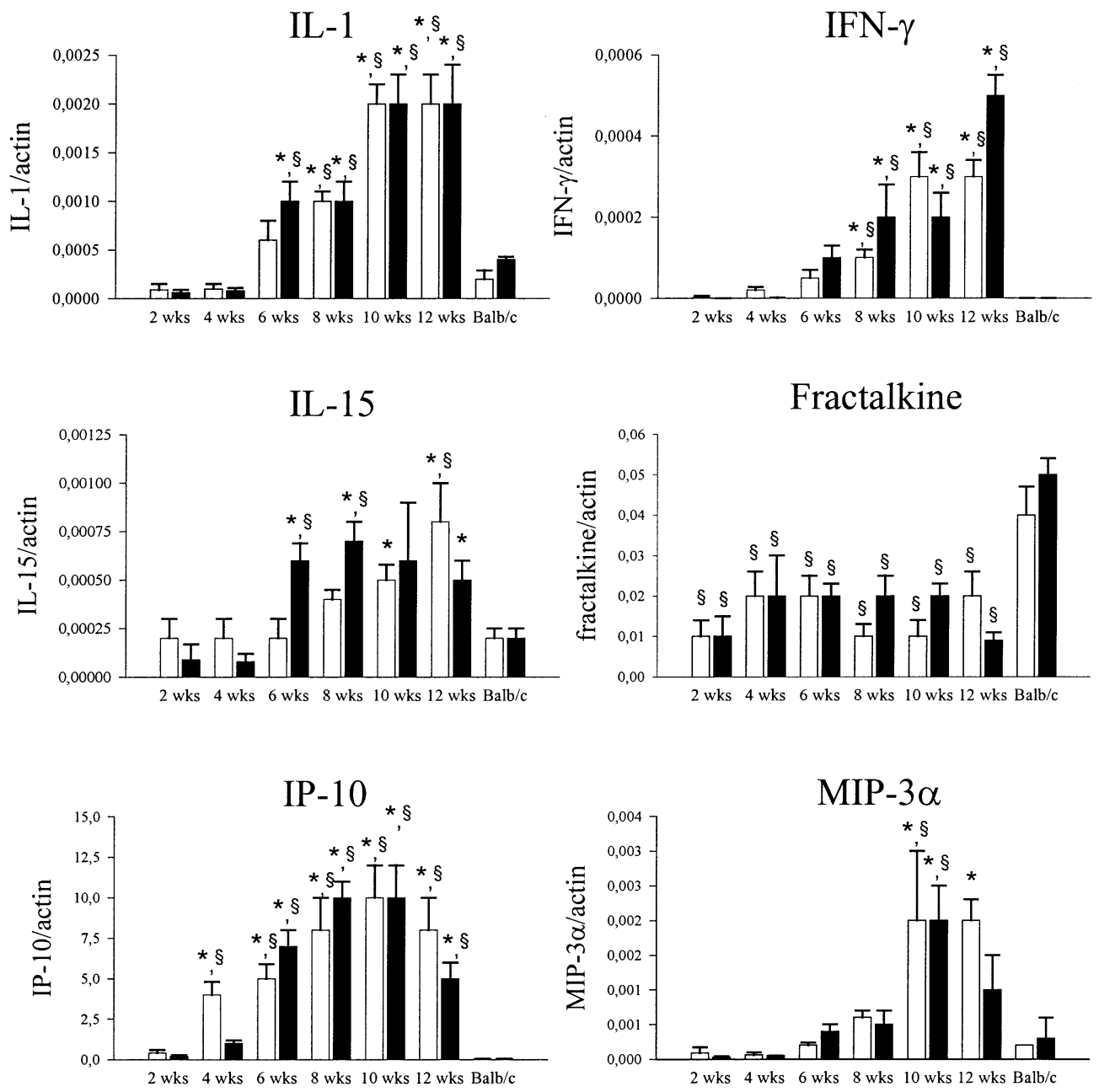

Fig. 4. Time course of IL-1 $\beta$, IFN- $\gamma$, IL-15, fractalkine, IP-10 and MIP-3 $\alpha$ mRNA expression in isolated islets from diabetesprone male $(\square)$ and female ( $\square$ ) NOD mice. Four-week-old male and female BALB/c islets were used as non-diabetesprone controls. The results were obtained by real time PCR, and are expressed as cytokine or chemokine copies/ $\beta$ actin copies. The data are shown as means \pm SEM. The pictures shown are representative on two to three similar experiments. $* p \leq 0.05$ vs. 2 -week-old NOD islets. $\S p \leq 0.05$ vs 4 -week-old $\mathrm{BALB} / \mathrm{c}$ islets. ANOVA followed by paired $t$-test with Bonferroni correction

tissue, while in BALB/c this increase was only threefold. Similar observations were made for MCP-1, where a 20-fold induction was observed in islets from NOD mice when compared to kidney tissue, whereas only a five-fold increase was detected in BALB/c mice (Fig. 5A). A similar increase in MIP-3 $\alpha$ expression was present in NOD and BALB/c mice (Fig. 5A). IL-15 was not changed in both mouse strains and fractalkine was slightly raised $8 \mathrm{~h}$ after transplantation in NOD mice.

Six days after transplantation the mRNA expression of cytokine and chemokines returned to basal levels in $\mathrm{BALB} / \mathrm{c}$ mice, except for a persistent and mild increase in MIP-3 $\alpha$ (Fig. 5B). In contrast, NOD

mice had high mRNA contents for IL-1 $\beta$, IFN- $\gamma$, MCP-1, IP-10 and MIP-3 $\alpha$ (Fig. 5B). After 6 days the heavy infiltration of mononuclear cells in NOD isografts can also be a source of chemokine/cytokine expression.

\section{Discussion}

Infiltrating macrophages and auto reactive T-cells participate in the destruction of islet beta cells in Type 1 diabetes, mediating the local inflammatory reaction (insulitis) and contributing to selective beta-cell damage $[1,3,6]$. The type of inflammatory infiltrate characterizing immune-mediated diseases is controlled, at least in part, by the subgroup of chemokines expressed in and around the target tissue [11]. Recent evidence suggests that chemokines could play a role in the pathogenesis of Type 1 diabetes. FACS-purified rat beta cells exposed to IL- $1 \beta$ and IFN- $\gamma$ or to double stranded RNA have increased mRNA expression for several cytokines and chemokines including MCP-1, IP-10, MIP-3 $\alpha$, fractalkine and IL-15 [8, 9, 47], and transgenic expression of MCP-1 in beta cells leads to insulitis [48]. These results were intriguing, and suggested that the highly differentiated beta cells would 

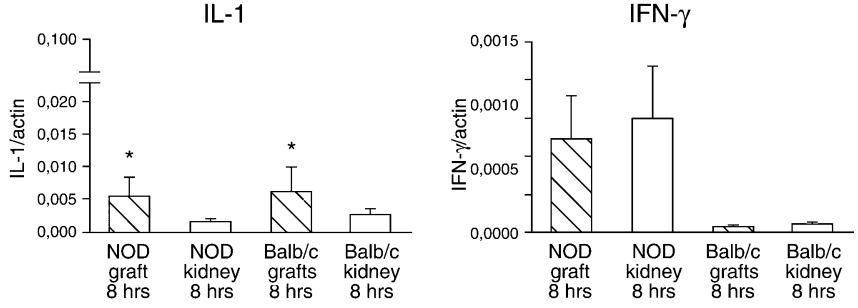

IL-15
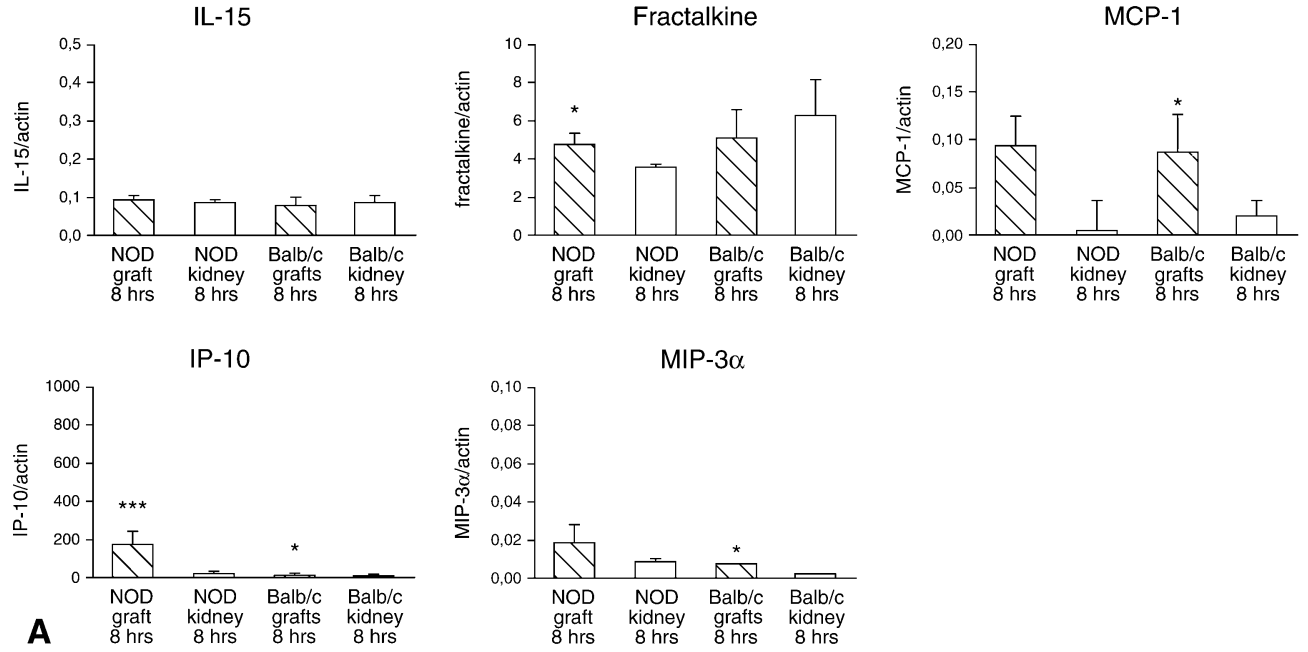

$\mathrm{IL}-1$
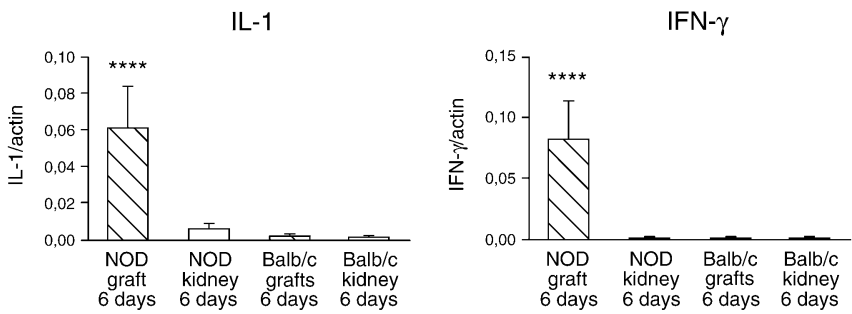

IL-15

Fractalkine

MCP-1
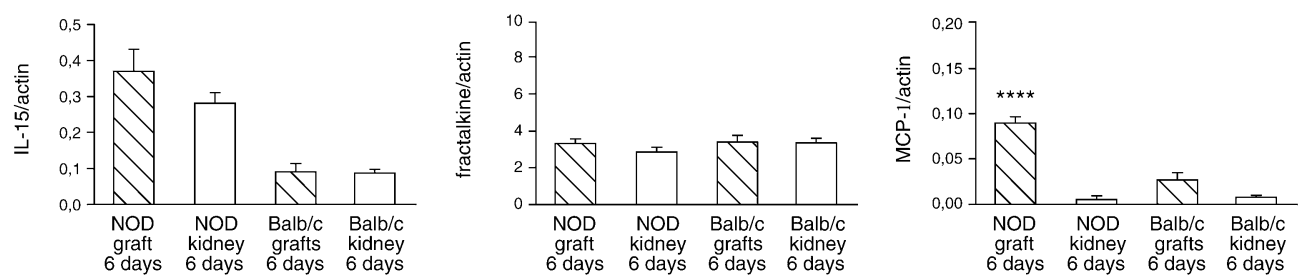

IP-10

MIP-3 $\alpha$
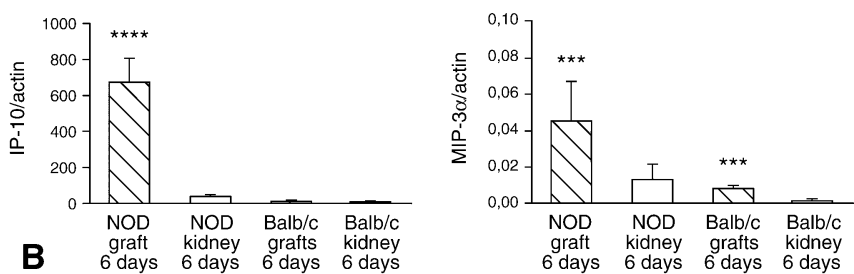

Fig. 5. (A,B) Expression of IL-1 $\beta$, IFN- $\gamma$, IL-15, fractalkine, IP-10, MIP-3 $\alpha$ and MCP-1 mRNAs in NOD and BALB/c islet isografts $8 \mathrm{~h}(\mathbf{A})$ and 6 days $(\mathbf{B})$ post transplantation into respectively diabetic NOD and BALB/c mice. The results were obtained by real-time RT-PCR analysis, and are shown as means \pm SEM, expressed relative to $\beta$-actin PCR product am- plified from the same sample (cytokine or chemokine copies/ $\beta$-actin copies). Significance $(*)$ is expressed compared to mRNA expression levels in respective control kidney tissue. $* p \leq 0.05, * * * p \leq 0.005$, ****p $\leq 0.001$, ***** $p \leq 0.0005$. ANOVA followed by paired $t$-test with Bonferroni correction 
produce chemokines following exposure to cytokines or viral products.

In this study we show for the first time that human islet cells exposed to IL-1 $\beta$ and IFN- $\gamma$ have increased mRNA expression of IL-15, IP-10, MIP-3 $\alpha$ and fractalkine and produce and secrete IL-15, IP-10, Mig, I-TAC and MIP-3 $\alpha$ protein into the culture medium. A constitutive expression of IL-15 was observed human islets (control), as described for kidney proximal tubule cells, astrocytes and microglia [49]. The nature of IL-15 function in non-stimulated cells requires further investigation. The main inducer of IL-15 in human islets and rat purified beta cells was IFN- $\gamma$. Similarly, IFN- $\gamma$ induces IL-15 mRNA expression in monocytes and NK cells $[49,50,51]$. The concentrations of IL-15 produced by human islets were low, similar to data obtained in other cell types [49, 52]. It has been shown that picomolar amounts of IL-15 are effective in maintaining $\mathrm{NK}$ cell survival in serum-free media [49], suggesting that the observed IL-15 production by human islets might be physiologically relevant.

As observed for IL-15, the induction of IP-10 was mostly mediated by IFN- $\gamma$. This induction was followed by the release of large amounts of IP-10 in the culture medium, in the range of 20 to $60 \mathrm{nmol} / \mathrm{l}$ per 1000 islets. Please note that $3 \mathrm{nmol} / \mathrm{l}$ of IP-10 is sufficient to trigger a chemotactic response in lymphocytes [53]. A synergistic effect of IL-1 $\beta$ and TNF- $\alpha$ with IFN- $\gamma$ in IP-10 protein release was detected and similar results were observed in thyroid follicular cells [15]. Besides IP-10 two other chemokines that bind to the CXCR3 receptor were induced by IFN- $\gamma$ in human islets, i.e. Mig and I-TAQ. Mig and I-TAQ have similar effects as IP-10, namely attraction of monocytes and activated Th1 cells and NK cells [14, 46, 54, 55], indicating that production of these three chemokines by islet cells could contribute to mononuclear, NK and Th1 cells homing in early insulitis.

Both TNF- $\alpha$ and IL- $1 \beta$ induced MIP- $3 \alpha$ protein secretion by human islets, but the induction by IL- $1 \beta$ was 20 -fold higher than that by TNF- $\alpha$. It is noteworthy that IFN- $\gamma$ inhibits MIP-3 $\alpha$ production by both TNF- $\alpha$ and IL-1 $\beta$. IL- $1 \beta$ and/or TNF- $\alpha$ induce MIP$3 \alpha$ in different cell types including keratinocytes, melanocytes, fibroblasts and monocytes $[22,23,56]$, but the inhibitory effect of IFN- $\gamma$ has not, to our knowledge, been previously described. On the contrary, IFN- $\gamma$ induces MIP- $3 \alpha$ protein expression in human keratinocytes [23], emphasizing the different regulation of chemokine expression in diverse cell types.

To evaluate whether IL-15, IP-10, MIP- $3 \alpha$ and factalkine are indeed expressed in pancreatic islets during early insulitis, we examined their mRNA expression in islets isolated from diabetes-prone NOD mice in the pre-diabetic stage. The mRNA expression of IL-15, IP-10 and MIP-3 $\alpha$ in human islets correlates well with protein production (present data), suggesting that increased expression of these mRNAs in NOD islets is associated to protein release in the islet microenvironment. It can not be excluded, however, that some of the observed changes in mRNA expression are not paralleled by similar changes in protein expression. Increased levels of IP-10 mRNA were observed already at 4 to 6 weeks of age before major insulitis is present [8]. In agreement with our mRNA data, high expression of IP-10 protein was also observed in islet cells from NOD mice at 8 weeks of age [12]. Increased IP-10 mRNA content is paralleled by increased expression of MCP-1 mRNA [8]. Macrophages are the first cells to infiltrate the islets in both NOD mice and BB rats [6, 57]. Activated macrophages are toxic to pancreatic islets in vitro [58] and macrophage depletion or inactivation prevent diabetes in BB rats and NOD mice $[59,60]$. IP-10 was reported to attract monocytes [61], and it is therefore conceivable that the early expression of IP-10 (current data) and MCP-1 [8] by NOD islet cells contributes to the recruitment of macrophages in the early stages of insulitis. In this context, it is puzzling that IP-10 expression seems to precede a detectable increase in IFN- $\gamma$, the main IP-10 inducer.

In agreement with the in vitro data, the induction of IL-15 mRNA in NOD islets was paralleled by increased IFN- $\gamma$ expression ( 6 weeks), while MIP-3 $\alpha$ induction coincided with the peak of IL-1 $\beta$ (10 weeks). Induction of IL-15 mRNA has been previously reported in cyclophosphamide-induced insulits in NOD mice [62]. The expression of IL-15, IP-10 and MIP-3 $\alpha$ in NOD islets (present data) occurs in parallel to infiltration by macrophages, dendritic cells, T helper and cytotoxic lymphocytes, and NK cells in NOD islets which is observed around 4 to 10 weeks [2]; from 10 to 12 weeks $80 \%$ of the NOD mice of our colony had intense insulitis [8]. T-cells are essential for the development of diabetes in both NOD mice and $\mathrm{BB}$ rats $[2,3]$, and the increased expression of IP-10, IL-15 and MIP-3 $\alpha$ by the islets might contribute to T-cell recruitment. The production of MIP- $3 \alpha$ could also be involved in the attraction of dendritic cells. It is noteworthy that the pattern of cytokine/ chemokine expression was similar in both male and female NOD mice, except for a late induction of IL-15 in males. Male and female NOD mice develop peripheral insulitis at the same age, but beta-cell destruction and diabetes mellitus are more prevalent in female NOD mice [4, 5, 63]. This suggests that increased chemokine expression has a more important role in the recruitment and homing of immune cells than in the later phase of destructive insulitis.

Diabetic NOD mice transplanted with syngeneic islets show early recurrence of the disease [38, 39]. Histological analysis indicates severe infiltration and destruction of more than $50 \%$ of the grafts already 6 days after transplantation [38]. Both CD4+ and CD8+ T-cells producing Th1-type cytokines (principally IFN$\gamma$ ), are involved in the destruction of beta cells [39]. 
We have previously shown [64] and confirmed in this study that a state of inflammation with high local expression of IL-1 is demonstrated immediately after (8-h) islet transplantation in autoimmune NOD mice. IL-1 expression was also increased in BALB/c mice isografts, suggesting that this is probably secondary to non-specific tissue damage associated to the early engraftment. This inflammatory environment might induce progressive production of chemokines by islets transplanted into diabetes-prone NOD mice contributing to their own destruction. In contrast, in a non-diabetes-prone strain, such as BALB/c, cytokine and chemokine expression decreases to basal levels after 6 days, suggesting resolution of the inflammation. We found high induction of IP-10 and MCP-1 $8 \mathrm{~h}$ after transplantation in NOD mice, as compared with kidney. Interestingly, an early IP-10 production (24-h) was also observed in heart isografts [65]. IP-10 production by these grafts was associated with leukocyte infiltration and graft injury, and the use of anti-IP-10 antibodies prolonged graft survival [65]. Besides its chemotactic activities, IP-10 and Mig are potent inhibitors of angiogenesis [66]. An adequate revascularization is crucial for islet survival and function after transplantation. Islet revascularization occurs within 7 to 14 days after transplantation [67], but the islet vascular density of the graft is clearly decreased as compared to endogenous islets [68]. Thus, the high expression of IP-10 in syngeneic NOD islets could contribute to poor graft vascularization and beta-cell survival.

Expression of IL-1 $\beta$ and MCP-1 was observed in syngeneic NOD islets $8 \mathrm{~h}$ after transplantation and it was maintained for at least 6 days. Since IL- $1 \beta$ is the main inducer of MCP-1 by pancreatic islet cells in vitro $[7,8]$, it is conceivable that increased IL- $1 \beta$ production is responsible for the early increase in graft MCP-1 expression. It is noteworthy that use of an IL-1 receptor antagonist prevents the recurrence of diabetes after syngeneic islet transplantation to diabetic NOD mice [69]. MCP-1 mRNA expression was also shown to be up-regulated in rat renal isografts [70] and the chemokine probably plays a role in the attraction of mononuclear cells to the graft. In line with this possibility, high basal MCP-1 production by human islets correlates with a poor clinical outcome following islet transplantation in patients with Type 1 diabetes [71].

At 6 days after transplantation, a time point where florid infiltration by immune cells is present, not only high levels of MCP-1 and IP-10 were maintained, but also high levels of MIP-3 $\alpha$ were measured. MIP- $3 \alpha$ might contribute to the attraction of memory T-cells to the grafts [20, 21]. Expression of IL-15 in the graft and kidney tissue was constitutive, with no major changes in expression after $8 \mathrm{~h}$ or 6 days. These observations contrast with the findings obtained in islets isolated from pre-diabetic NOD mice, showing a pro- gressive increase in IL-15 expression. This suggests potential differences in the mechanisms that regulate the homing of lymphocytes and monocytes in the endogeneous pancreas of NOD mice or following syngeneic transplantation in diabetic animals.

In conclusion, we have shown expression of several chemokines and IL-15 in FACS-purified rat beta cells and human islets exposed to cytokines in vitro, as well as in NOD islets from pre-diabetic mice or during isograft rejection. The conserved expression of IP-10, MIP-3 $\alpha$, MCP-1 and IL-15 in three different species, and the good correlation between the in vitro and in vivo data, suggests that chemokines and IL-15 produced by islet cells are involved in the recruitment of immune-cells during both insulitis and islet graft destruction.

Acknowledgements. We acknowledge the assistance from the Diabetes Research Centre (VUB) personnel involved in betacell purification, and the help of R. Leeman, F. Mahieu and E. Quartier. We thank K. Vercruysse for help in the experiments with RINm5F cells. We are grateful to The $\beta$-Cell Transplant Brussels, for providing access to human islet cells. This work was supported by grants from the Juvenile Diabetes Foundation International, the Government of Flanders (GOA 99/10), the Belgium National Ministry of Science (IUAP P4/21), the Flemish Research Foundation [Fonds Voor Wetenschappelijk Onderzoek (FWO)] and the OnderzoeksraadVUB. This work has been conducted in collaboration with and supported by the JDRF Centre for Prevention of Beta-Cell Destruction in Europe under grant number 4-2002-457. P. Proost and C. Mathieu are postdoctoral fellows of the FWO.

\section{References}

1. Kukreja A, Maclaren NK (1999) Autoimmunity and diabetes. J Clin Endocrinol Metab 84:4371-4378

2. Yoon JW, Jun HS, Santamaria P (1998) Cellular and molecular mechanisms for the initiation and progression of $\beta$-cell destruction resulting from the collaboration between macrophages and T cells. Autoimmunity 27:109-122

3. Thomas HE, Kay TW (2000) $\beta$-Cell destruction in the development of autoimmune diabetes in the non-obese diabetic (NOD) mouse. Diabetes Metab Res Rev 16:251-261

4. Casteels K, Waer M, Bouillon R et al. (1998) 1,25-Dihydroxyvitamin D3 restores sensitivity to cyclophosphamideinduced apoptosis in non-obese diabetic (NOD) mice and protects against diabetes. Clin Exp Immunol 112:181-187

5. Makino S, Kunimoto K, Muraoka Y, Mizushima Y, Katagiri K, Tochino Y (1980) Breeding of a non-obese, diabetic strain of mice. Jikken Dobutsu 29:1-13

6. Eizirik DL, Mandrup-Poulsen T (2001) A choice of deaththe signal-transduction of immune-mediated $\beta$-cell apoptosis. Diabetologia 44:2115-2133

7. Chen MC, Schuit F, Eizirik DL (1999) Identification of IL-1 $\beta$-induced messenger RNAs in rat pancreatic $\beta$-cells by differential display of messenger RNA. Diabetologia 42:1199-1203

8. Chen MC, Proost P, Gysemans C, Mathieu C, Eizirik DL (2001) Monocyte chemoattractant protein-1 is expressed in pancreatic islets from prediabetic NOD mice and in interleukin-1 $\beta$-exposed human and rat islet cells. Diabetologia 44:325-332 
9. Cardozo AK, Kruhoffer M, Leeman R, Orntoft T, Eizirik DL (2001) Identification of novel cytokine-induced genes in pancreatic $\beta$-cells by high-density oligonucleotide arrays. Diabetes 50:909-920

10. Cardozo AK, Heimberg H, Heremans Y et al. (2001) A comprehensive analysis of cytokine-induced and nuclear factor- $\kappa \mathrm{B}$-dependent genes in primary rat pancreatic $\beta$-cells. J Biol Chem 276:48879-48886

11. Luster AD (1998) Chemokines-chemotactic cytokines that mediate inflammation. N Engl J Med 338:436-445

12. Arimilli S, Ferlin W, Solvason N, Deshpande S, Howard M, Mocci S (2000) Chemokines in autoimmune diseases. Immunol Rev 177:43-51

13. Loetscher M, Loetscher P, Brass N, Meese E, Moser B (1998) Lymphocyte-specific chemokine receptor CXCR3: regulation, chemokine binding and gene localization. Eur J Immunol 28:3696-3705

14. Taub DD, Sayers TJ, Carter CR, Ortaldo JR (1995) Alpha and beta chemokines induce NK cell migration and enhance NK-mediated cytolysis. J Immunol 155:3877-3888

15. Garcia-Lopez MA, Sancho D, Sanchez-Madrid F, Marazuela M (2001) Thyrocytes from autoimmune thyroid disorders produce the chemokines IP-10 and Mig and attract CXCR3+ lymphocytes. J Clin Endocrinol Metab 86:5008-5016

16. Kieseier BC, Tani M, Mahad D et al. (2002) Chemokines and chemokine receptors in inflammatory demyelinating neuropathies: a central role for IP-10. Brain 125:823-834

17. Fife BT, Kennedy KJ, Paniagua MC et al. (2001) CXCL10 (IFN- $\gamma$-inducible protein-10) control of encephalitogenic CD4+ $\mathrm{T}$ cell accumulation in the central nervous system during experimental autoimmune encephalomyelitis. J Immunol 166:7617-7624

18. Shimada A, Morimoto J, Kodama K et al. (2001) Elevated serum IP-10 levels observed in type 1 diabetes. Diabetes Care 24:510-515

19. Hieshima K, Imai T, Opdenakker G et al. (1997) Molecular cloning of a novel human $\mathrm{CC}$ chemokine liver and activation-regulated chemokine (LARC) expressed in liver. Chemotactic activity for lymphocytes and gene localization on chromosome 2. J Biol Chem 272:5846-5853

20. Power CA, Church DJ, Meyer A et al. (1997) Cloning and characterization of a specific receptor for the novel $\mathrm{CC}$ chemokine MIP-3 $\alpha$ from lung dendritic cells. J Exp Med 186:825-835

21. Liao F, Rabin RL, Smith CS, Sharma G, Nutman TB, Farber JM (1999) CC-chemokine receptor 6 is expressed on diverse memory subsets of $\mathrm{T}$ cells and determines responsiveness to macrophage inflammatory protein $3 \alpha$. J Immunol 162:186-194

22. Homey B, Dieu-Nosjean MC, Wiesenborn A et al. (2000) Up-regulation of macrophage inflammatory protein$3 \alpha /$ CCL20 and CC chemokine receptor 6 in psoriasis. J Immunol 164:6621-6632

23. Nakayama T, Fujisawa R, Yamada H et al. (2001) Inducible expression of a CC chemokine liver- and activationregulated chemokine (LARC)/macrophage inflammatory protein (MIP)-3 $\alpha /$ CCL20 by epidermal keratinocytes and its role in atopic dermatitis. Int Immunol 13:95-103

24. Matsui T, Akahoshi T, Namai R et al. (2001) Selective recruitment of CCR6-expressing cells by increased production of MIP-3 $\alpha$ in rheumatoid arthritis. Clin Exp Immunol 125:155-161

25. Shimizu Y, Murata H, Kashii Y et al. (2001) CC-chemokine receptor 6 and its ligand macrophage inflammatory protein $3 \alpha$ might be involved in the amplification of local necroinflammatory response in the liver. Hepatology 34:311-319
26. Bazan JF, Bacon KB, Hardiman G et al. (1997) A new class of membrane-bound chemokine with a CX3C motif. Nature 385:640-644

27. Yoneda O, Imai T, Goda S et al. (2000) Fractalkine-mediated endothelial cell injury by NK cells. J Immunol 164:40554062

28. Fong AM, Robinson LA, Steeber DA et al. (1998) Fractalkine and CX3CR1 mediate a novel mechanism of leukocyte capture, firm adhesion, and activation under physiologic flow. J Exp Med 188:1413-1419

29. Robinson LA, Nataraj C, Thomas DW et al. (2000) A role for fractalkine and its receptor (CX3CR1) in cardiac allograft rejection. J Immunol 165:6067-6072

30. Haskell CA, Hancock WW, Salant DJ et al. (2001) Targeted deletion of CX(3)CR1 reveals a role for fractalkine in cardiac allograft rejection. J Clin Invest 108:679688

31. Cockwell P, Chakravorty SJ, Girdlestone J, Savage CO (2002) Fractalkine expression in human renal inflammation. J Pathol 196:85-90

32. Kirman I, Vainer B, Nielsen OH (1998) Interleukin-15 and its role in chronic inflammatory diseases. Inflamm Res 47:285-289

33. Pipeleers DG, in't Veld PA, Van de Winkel M, Maes E, Schuit FC, Gepts W (1985) A new in vitro model for the study of pancreatic A and B cells. Endocrinology 117:806816

34. Ling Z, Hannaert JC, Pipeleers D (1994) Effect of nutrients, hormones and serum on survival of rat islet $\beta$-cells in culture. Diabetologia 37:15-21

35. Keymeulen B, Ling Z, Gorus FK et al. (1998) Implantation of standardized $\beta$-cell grafts in a liver segment of IDDM patients: graft and recipients characteristics in two cases of insulin-independence under maintenance immunosuppression for prior kidney graft. Diabetologia 41:452-459

36. Ling Z, Pipeleers DG (1996) Prolonged exposure of human $\beta$-cells to elevated glucose levels results in sustained cellular activation leading to a loss of glucose regulation. J Clin Invest 98:2805-2812

37. Pozzilli P, Signore A, Williams AJ, Beales PE (1993) NOD mouse colonies around the world-recent facts and figures. Immunol Today 14:193-196

38. Casteels K, Waer M, Laureys J et al. (1998) Prevention of autoimmune destruction of syngeneic islet grafts in spontaneously diabetic nonobese diabetic mice by a combination of a vitamin D3 analog and cyclosporine. Transplantation 65:1225-1232

39. Suarez-Pinzon W, Rajotte RV, Mosmann TR, Rabinovitch A (1996) Both CD4+ and CD8+ T-cells in syngeneic islet grafts in NOD mice produce interferon- $\gamma$ during $\beta$-cell destruction. Diabetes 45:1350-1357

40. Liu D, Darville M, Eizirik DL (2001) Double-stranded ribonucleic acid (RNA) induces $\beta$-cell Fas messenger RNA expression and increases cytokine-induced $\beta$-cell apoptosis. Endocrinology 142:2593-2599

41. Overbergh L, Valckx D, Waer M, Mathieu C (1999) Quantification of murine cytokine mRNAs using real time quantitative reverse transcriptase PCR. Cytokine 11:305312

42. Giulietti A, Overbergh L, Valckx D, Decallonne B, Bouillon R, Mathieu C (2001) An overview of real-time quantitative PCR: applications to quantify cytokine gene expression. Methods 25:386-401

43. Eizirik DL, Flodstrom M, Karlsen AE, Welsh N (1996) The harmony of the spheres: inducible nitric oxide synthase and related genes in pancreatic $\beta$-cells. Diabetologia 39:875-890 
44. Eizirik DL, Pavlovic D (1997) Is there a role for nitric oxide in $\beta$-cell dysfunction and damage in IDDM? Diabetes Metab Rev 13:293-307

45. John NE, Andersen HU, Fey SJ et al. (2000) Cytokine- or chemically-derived nitric oxide alters the expression of proteins detected by two-dimensional gel electrophoresis in neonatal rat islets of Langerhans. Diabetes 49:1819-1829

46. Tensen CP, Flier J, Van Der Raaij-Helmer EM et al. (1999) Human IP-9: A keratinocyte-derived high affinity CXCchemokine ligand for the IP-10/Mig receptor (CXCR3). J Invest Dermatol 112:716-722

47. Liu D, Cardozo AK, Darville MI, Eizirik DL (2002) Double-stranded RNA cooperates with interferon- $\gamma$ and IL-1 $\beta$ to induce both chemokine expression and nuclear factor- $\kappa \mathrm{B}$-dependent apoptosis in pancreatic $\beta$-cells: potential mechanisms for viral-induced insulitis and $\beta$-cell death in type 1 diabetes mellitus. Endocrinology 143:12251234

48. Grewal IS, Rutledge BJ, Fiorillo JA et al. (1997) Transgenic monocyte chemoattractant protein-1 (MCP-1) in pancreatic islets produces monocyte-rich insulitis without diabetes: abrogation by a second transgene expressing systemic MCP-1. J Immunol 159:401-408

49. Fehniger TA, Caligiuri MA (2001) Interleukin 15: biology and relevance to human disease. Blood 97:14-32

50. Bamford RN, Battiata AP, Burton JD, Sharma H, Waldmann TA (1996) Interleukin (IL) 15/IL-T production by the adult T-cell leukemia cell line HuT-102 is associated with a human T-cell lymphotrophic virus type I region/ IL-15 fusion message that lacks many upstream AUGs that normally attenuates IL-15 mRNA translation. Proc Natl Acad Sci USA 93:2897-2902

51. Musso T, Calosso L, Zucca M et al. (1999) Human monocytes constitutively express membrane-bound, biologically active, and interferon- $\gamma$-upregulated interleukin-15. Blood 93:3531-3539

52. Verma S, Hiby SE, Loke YW, King A (2000) Human decidual natural killer cells express the receptor for and respond to the cytokine interleukin 15. Biol Reprod 62:959-968

53. Proost P, Schutyser E, Menten P et al. (2001) Amino-terminal truncation of CXCR3 agonists impairs receptor signaling and lymphocyte chemotaxis, while preserving antiangiogenic properties. Blood 98:3554-3561

54. Farber JM (1997) Mig and IP-10: CXC chemokines that target lymphocytes. J Leukoc Biol 61:246-257

55. Cole KE, Strick CA, Paradis TJ et al. (1998) Interferon-inducible $\mathrm{T}$ cell $\alpha$ chemoattractant (I-TAC): a novel nonELR CXC chemokine with potent activity on activated $\mathrm{T}$ cells through selective high affinity binding to CXCR3. J Exp Med 187:2009-2021

56. Schutyser E, Struyf S, Menten P et al. (2000) Regulated production and molecular diversity of human liver and activation-regulated chemokine/macrophage inflammatory protein- $3 \alpha$ from normal and transformed cells. J Immunol 165:4470-4477
57. Hanenberg H, Kolb-Bachofen V, Kantwerk-Funke G, Kolb $H$ (1989) Macrophage infiltration precedes and is a prerequisite for lymphocytic insulitis in pancreatic islets of pre-diabetic BB rats. Diabetologia 32:126-134

58. Schwizer RW, Leiter EH, Evans R (1984) Macrophagemediated cytotoxicity against cultured pancreatic islet cells. Transplantation 37:539-544

59. Jun, HS, Santamaria, P, Lim, HW, Zhang, ML, Yoon, JW (1999) Absolute requirement of macrophages for the development and activation of $\beta$-cell cytotoxic CD8+ T-cells in T-cell receptor transgenic NOD mice. Diabetes 48:34-42

60. Oschilewski U, Kiesel U, Kolb H (1985) Administration of silica prevents diabetes in BB-rats. Diabetes 34:197-199

61. Matsushima K, Larsen CG, DuBois GC, Oppenheim JJ (1989) Purification and characterization of a novel monocyte chemotactic and activating factor produced by a human myelomonocytic cell line. J Exp Med 169:1485-1490

62. Rothe H, Hausmann A, Kolb H (2002) Immunoregulation during disease progression in prediabetic NOD mice: inverse expression of arginase and prostaglandin $\mathrm{H}$ synthase 2 vs. interleukin-15. Horm Metab Res 34:7-12

63. Mathieu C, Waer M, Laureys J, Rutgeerts O, Bouillon R (1994) Prevention of autoimmune diabetes in NOD mice by 1,25 dihydroxyvitamin D3. Diabetologia 37:552-558

64. Gysemans CA, Waer M, Valckx D et al. (2000) Early graft failure of xenogeneic islets in NOD mice is accompanied by high levels of interleukin-1 and low levels of transforming growth factor- $\beta$ mRNA in the grafts. Diabetes 49:19921997

65. Hancock WW, Gao W, Csizmadia V, Faia KL, Shemmeri N, Luster AD (2001) Donor-derived IP-10 initiates development of acute allograft rejection. J Exp Med 193:975980

66. Strieter RM, Kunkel SL, Arenberg DA, Burdick MD, Polverini PJ (1995) Interferon $\gamma$-inducible protein 10 (IP-10), a member of the C-X-C chemokine family, is an inhibitor of angiogenesis. Biochem Biophys Res Commun 210:51-57

67. Jansson L, Carlsson P-O (2002) Graft vascular function after transplantation of pancreatic islets. Diabetologia 45:749-763

68. Mattsson G, Jansson L, Carlsson PO (2002) Decreased vascular density in mouse pancreatic islets after transplantation. Diabetes 51:1362-1366

69. Sandberg JO, Eizirik DL, Sandler S (1997) IL-1 receptor antagonist inhibits recurrence of disease after syngeneic pancreatic islet transplantation to spontaneously diabetic non-obese diabetic (NOD) mice. Clin Exp Immunol 108:314-317

70. Nadeau KC, Azuma H, Tilney NL (1995) Sequential cytokine dynamics in chronic rejection of rat renal allografts: roles for cytokines RANTES and MCP-1. Proc Natl Acad Sci USA 92:8729-8733

71. Piemonti L, Leone BE, Nano R et al. (2002) Human pancreatic islets produce and secrete MCP-1/CCL2: relevance in human islet transplantation. Diabetes 51:55-65 